\title{
CREDIT RATIONING AND PUBLIC SUPPORT OF COMMERCIAL CREDIT
}

\author{
Karel Janda
}
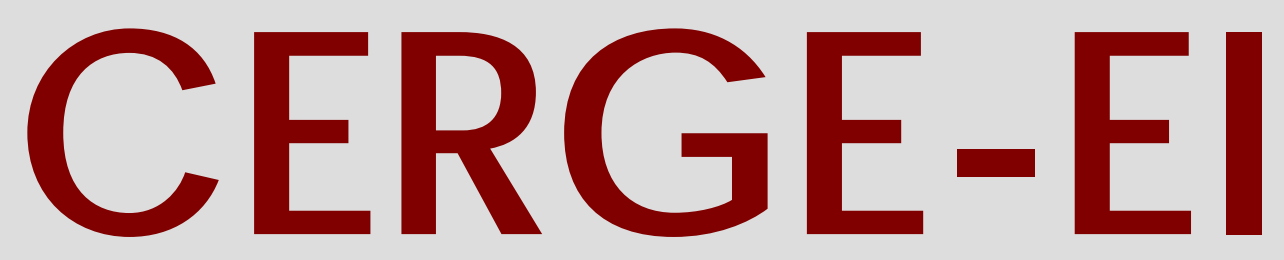

Charles University Centerfor Economic Research and Graduate Education Academy of Sciences of the Czech Republic Ec onomic Institute 


\title{
Working Paper Series 436 (ISSN 1211-3298)
}

\section{Credit Rationing and Public Support of Commercial Credit}

\author{
Karel Janda
}

CERGE-EI

Prague, April 2011 
ISBN 978-80-7343-237-9 (Univerzita Karlova. Centrum pro ekonomický výzkum a doktorské studium)

ISBN 978-80-7344-228-6 (Národohospodářský ústav AV ČR, v.v.i.) 


\title{
Credit Rationing and Public Support of Commercial Credit*
}

\author{
Karel Janda ${ }^{\dagger}$
}

April 1, 2011

\begin{abstract}
Credit contracting between a lender with monopoly market power and a small start-up entrepreneur may lead to the rejection of projects whose expected benefits are higher than their total costs. This inefficiency may be eliminated by government support in the form of credit guarantees or interest rate subsidies. This paper compares different forms of government support and concludes that credit guarantees and interest rate subsidies have a nonambiguous positive effect on social efficiency since they enable the financing of socially efficient projects which would not be financed otherwise. The comparison of government budget costs for these two types of government interventions depends on the institutional details and parametrization of the credit problem.
\end{abstract}

Keywords: credit, subsidy, guarantee

JEL Clasification: D82, G18, H25

${ }^{*}$ The work on this paper was supported by the Czech Science Foundation, grant numbers 402/11/0948, 403/10/1235, 402/09/0380, and by the research project MSM0021620841.

†Institute of Economic Studies of the Faculty of Social Sciences of Charles University, University of Economics, Prague, and Affiliate Fellow at CERGE-EI. Correspondence address: IES FSV UK, Opletalova 26, 11000 Praha 1, Czech Republic, Karel-Janda@seznam.cz. 


\begin{abstract}
Abstrakt
Úvěrový vztah mezi věřitelem s monopolním tržním postavením a malým začínajícím podnikatelem může vést $\mathrm{k}$ odmítnutí projektů, jejichz očekávané přínosy jsou vyšší než jejich očekávané náklady. Tato neefektivnost může být odstraněna poskytnutím státní podpory ve formě úvěrových záruk nebo úrokových dotací. Prezentovaný model srovnává různé formy státních podpor a dochází k závěru, že úvěrové garance a úrokové dotace mají jednoznačně kladný vliv na společenskou efektivnost neboť dovolují financování společensky efektivních projektů, které by jinak nebyly financovány. Srovnání nákladů státního rozpočtu nutných pro financování těchto dvou typů státních zásahů záleží na institucionálních podrobnostech a na parametrizaci daného úvěrového problému.
\end{abstract}




\section{Introduction}

Credit markets serve as a classical example of markets in which information asymmetry plays a significant role. Market failures generated by asymmetric information, especially credit rationing (STIGLITZ AND WEISS [1981]), open a place for government policy interventions such as credit guarantees (BECK, KLAPPER, AND MEndozA [2010]) or interest rate subsidies (DIAmOND [1997]). The need for these policy interventions is particularly pressing in times of financial and economic crises, when many legal restrictions on state aid are lifted, as documented in the sections "Aid in the Form of Guarantees" and "Aid in the Form of Subsidized Interest Rate" in the European Commission [2009] communication.

In this paper we show that adverse selection in a credit market with a lender who has market power may lead to inefficient credit rationing. We first characterize this market equilibrium, and then we investigate two types of government interventions (credit guarantees and interest rate subsidies) that enable financing of all socially efficient projects. Finally we compare the government budget costs of both of these interventions, and we conclude that in some situations credit guarantees are cheaper for the government. In other situations, it is less expensive to remove inefficient credit rationing through interest rate subsidies. This result provides theoretical support for the empirically observed fact that governments sometimes prefer subsidies and sometimes guarantees.

The problem of government interventions in credit markets under adverse selection has already been addressed in early theoretical models by MANKIW [1986], DeMEzA And Webb [1987], Smith And Stutzer [1989], Gale [1990], and Innes [1991]. All of these papers deal with Bertrand competition in perfectly competitive markets as opposed to our assumption of a lender's market power. They also did not investigate the government budget costs of the interventions they considered. The role of subsidies and guarantees considered in our model may be compared to the price subsidies which are used in monopoly regulation theory to induce the monopolist to produce a socially 
optimal quantity.

As opposed to our assumption of a fixed-size project, DeMEZA AND WeBB [1987] and INNES [1991] focus their attention on the efficiency of public interventions connected with the variable size of investment projects. A comparative analysis of different forms of public support of credit provision was recently provided by ARPING, LORANTH, AND MorRISON [2010]. As opposed to our comparison of credit guarantees and subsidies, ARPING ET AL. [2010] compare credit guarantees with co-funding of investment projects by credit support agencies. In a different setting from the one we consider, they find that government support funds should be channeled first to credit guarantee schemes and co-funding should be supported only when the entrepreneurs start to substitute public for private collateral.

The setting of our model is closest to Mineldi And Modica [2006], who, in their model regarding lenders' market power, show that interest rate subsidies and loan guarantees are optimal credit policies from a government budget point of view. They are cheaper than investment subsidies or collateral provision. As opposed to our characterization of the risk through first order stochastic dominance, MinelLi AND ModicA [2006] use a second-order-stochastic-dominance approach.

All of these papers, with the exception of SMith AND STUtzer [1989], assume a uniform participation cost for all types of investment projects. In our model we follow BECKER [1964] distinction of general and specific human capital. We assume that different general human capital leads to differences in opportunity costs among different types of entrepreneurs, while specific human capital determines the success probability of investment projects under consideration. Consequently, different mixes of general and specific human capital generate different outcomes in our model.

Out of the empirical literature dealing with government interventions in credit markets, the papers by JANDA [2006] and UESUGI [2008] are particularly relevant to our model. The Czech Supporting and Guarantee Agricultural and Forestry Fund investi- 
gated by JANDA [2006] and the Japanese Special Credit Guarantee Program for Financial Stability analyzed by UESUGI [2008] both provide their support to eligible small or medium-sized enterprises essentially automatically, in the same way that our model works. In addition, interest rate subsidies and guarantees are provided by the Czech Supporting and Guarantee Agricultural and Forestry Fund without any fee or premium paid by the borrower or lender. They are pure transfer payments from a government agency exactly as they are implemented in our model.

The role of credit guarantees was recently investigated in empirically-oriented papers by Cowling [2010], Columba, Gambacorta, And Mistrulli [2010], and HonoHAN [2010]. Cowling [2010] shows that the loan guarantee scheme initiated by the UK government in 1981 succeeded in alleviating binding credit constraints. CoLUmBA ET AL. [2010] consider the situation of information asymmetry between firms and banks similarly as we do in this paper. On a sample of Italian Mutual Guarantee Institutions, they show that credit constraints caused by information asymmetry may be alleviated through these institutions which allow for credible signaling of creditworthiness of their members without a need for government involvement. HoNOHAN [2010] presents in his survey of principles and practices of partial credit guarantees a list of difficulties associated with the practical evaluation of the actual fiscal cost of credit guarantees. He also emphasizes that the attraction of credit guarantees for public policy can be misleading. He argues that the most attractive feature of credit guarantees for myopic politicians may be the ease with which the true costs of guarantees can be understated at the outset of the credit guarantee program.

The analysis of government interventions in the credit market is done in this paper in the framework of a standard principal-agent model of adverse selection, in which the principal has market power allowing him to extract positive profits. The empirical investigation of market power in the banking sector is a subject of both academic research and anti-monopoly regulation. 
Neven AND Roller [1999] developed and estimated a model for the European banking industry which controls for asymmetries in market structure. They rejected noncooperative Nash behavior in favor of more collusive cartel-like conduct. Such exercise of market power by banks leads to many legal investigations. An example of such anticartel action may be the widely publicized investigation by the Czech Office for the Protection of Competition of the three biggest Czech banks in 2005. The suspicion of the existence of a secret cartel agreement among those banks was not confirmed, and the investigation was terminated, but the Office still closely monitors the Czech banking market for the signs of illegal collusive behavior.

The existence of market power of a lender is very characteristic for the banking sector in many emerging markets. A recent empirical study by BIKKER, SPIERDIJK, AND FinNIE [2007] based on Bankscope data covering 76 countries for 1995-2004 concludes that "competition is substantially weaker in countries with a socialist past, such as Central- and Eastern Europe." Similar results are reported by MAUdos AND NAGorE [2005] for a sample of 58 countries for 1995-1999.

Pruteanu-Podpiera, Schobert, And Weill [2008] explicitly investigate market power in the Czech banking sector for the period 1994-2005 using exhaustive quarterly data for all Czech banks. Applying the Lerner index they measure the competition level on the loan market using data on loan prices. Their results confirm that the market power of Czech banks is higher than world-wide or European averages. Their results also do not show a clear-cut trend in the evolution of the Lerner index for the Czech banking sector. This means that convergence to the average market power level in the banking sector of developed European economies is still very slow. In this context of comparing the Czech banking sector as a representative of emerging European economies with developed European countries, it has to be stressed that the empirical literature on banking sectors in developed economies, (for example, HEMPELL [2002]) in general concludes in favor of imperfect competition. Therefore, strong foreign ownership of Czech 
banks might favor the ongoing process of convergence toward the usual characteristics in the European banking industry even if a strong level of banking competition is not observed.

Similar results with respect to the existence of market power are obtained by testing the implications of the Rosse-Panzar model. This non-structural test is based upon the estimation of the H-statistic, which aggregates the elasticities of total revenues to input prices. It has been applied in Western European countries by BIKKER AND HAAF [2002], Hempell [2002] and Weill [2004]. Gelos And Roldos [2004] applied this model to eight emerging countries, including three transition countries (the Czech Republic, Hungary and Poland). They conclude in favor of monopolistic competition in these three countries, and they also confirm the absence of a significant change in banking competition between 1994 and 1999 in these transition countries.

\section{The Baseline Model}

We model the provision of credit in a principal-agent model of adverse selection. The setting of our model follows the classic papers by CHAN AND KanATAS [1985], Bester [1985], Besanko and Thakor [1987], and Gale [1990].

There are three classes of economic agents in our model: government, lenders, and borrowers. The government is modeled as a benevolent body whose only concern is an increase in social efficiency and whose only role is to distribute exogenously determined guarantees and subsidies. The role of lenders is to provide financial funds which are needed by borrowers in order to realize their projects. Risk-neutral lenders are effectively colluded and act as a single principal with market power. The supply of funds facing lenders is perfectly elastic so that the lenders have any demanded amount of funds under the unit cost of $\rho$ available.

There are two types of risk neutral borrowers in this model, indexed as Type 1

and Type 2. These two types are distinguished by different specific human capital 
which determines their chances of successfully finishing their project, denoted as $0<$ $\delta_{1}<\delta_{2}<1$, and by different general human capital which determines their reservation utilities from not participating in the project, denoted as $b_{1}$ and $b_{2}$. A Type 1 borrower is labeled as a high-risk borrower and a Type 2 borrower as a low-risk borrower. The probability that a random borrower facing a lender is a Type 1 borrower is $\theta$, which is the proportion of Type 1 borrowers in the total population of borrowers.

The borrower can either undertake one risky project, which yields $y$ in the case of success and 0 in the case of failure, or he can become engaged in some other activity, which yields an expected return of $b_{i}, i \in\{1,2\}$. We assume that the project has a positive net present value:

$$
\delta_{i} y>b_{i}+\rho .
$$

In order to undertake the project, the borrower has to borrow a fixed amount of money from the lender. The size of this loan is normalized to 1.

The values of all parameters are known by borrowers, lenders and government. The only informational asymmetry in the model is that lenders and government do not know the type of borrower.

The flow of funds from lenders to borrowers and the repayment of these funds is governed by contracts. Each lender offers two types of contracts. Each contract is a pair $\left(\pi_{i}, R_{i}\right), i \in\{1,2\}$ where the first term is the probability that the application of the borrower who chooses this contract will be satisfied and he will actually be loaned money, and the second term is the interest factor $(1+$ interest rate $)$, which is equal to the required repayment because of our normalization of the loan size to 1 . The solution of our model will show that in equilibrium applicants are rejected or accepted with a probability of 1 .

The expected utility of a borrower of Type $i$ who applies for a contract designed for a borrower of Type $j$ is given by 


$$
U_{i j}=\pi_{j}\left[\delta_{i}\left(y-R_{j}\right)-b_{i}\right]
$$

The lender's expected profit on one loan provided to a borrower of Type $i$ is given as

$$
B_{i}=\pi_{i}\left[\delta_{i} R_{i}-\rho\right]
$$

We assume that in the case that a lender is indifferent between lending and not lending, he resolves this tie in favor of lending. Similarly, the borrower who is indifferent to accepting a credit contract and abandoning his project will decide to take the contract.

\section{Economy without Government Intervention}

As a benchmark against which inefficiencies caused by information asymmetries can be evaluated, we first consider the symmetric information case. Under this scenario the lender has exactly the same information as borrowers, and he is able to separate borrowers perfectly into two different markets. The optimal contract for the lender with market power is the one in which he maximizes his expected profit subject to the individual rationality (participation) constraint for entrepreneurs who want to borrow money:

$$
\max _{\left(\pi_{i}, R_{i}\right)} B=\pi_{i}\left[\delta_{i} R_{i}-\rho\right]
$$

s.t.

$$
\begin{gathered}
\pi_{i}\left[\delta_{i}\left(y-R_{i}\right)-b_{i}\right] \geq 0, \\
0 \leq \pi_{i} \leq 1 \\
i \in\{1,2\} .
\end{gathered}
$$


The solution to this inequality constraint problem is given by

$$
\begin{aligned}
R_{i}^{s} & =y-\frac{b_{i}}{\delta_{i}}, \\
\pi_{i}^{s} & =1, \\
i & \in\{1,2\} .
\end{aligned}
$$

As long as the lender has the same information as the borrower, he is able to extract the entire surplus. This means that the individual rationality constraints (IRi) of a borrower $i$ is binding. There is no inefficiency in this case since the project is financed and undertaken if and only if the expected return of a project $\left(\delta_{i} y\right)$ is equal or bigger than the social cost $\left(b_{i}+\rho\right)$. Therefore under our Assumption 1 of the positive net present value, the project would be financed by the lender who is able to costlessly distinguish between good and bad entrepreneurs. The repayment required by the lender differs according to ratio $\frac{b_{i}}{\delta_{i}}, i \in\{1,2\}$ with the entrepreneur with a lower ratio being asked a higher repayment. This is intuitive as the lower the ratio is, the lower the outside option and the higher the probability of success, i.e., the borrower is willing to pay back more in order to be able to run the project.

The financing decision of the lender is efficient, and consequently there is no efficiency reason for government intervention in this case. Obviously the full extraction of the entire surplus by the lender is possible only if he is institutionally allowed to charge a different type of borrower a different interest rate. That is, our solution assumes that the lender is allowed perfectly to discriminate between different customers.

In the rest of this paper we will investigate cases when the introduction of information asymmetry between borrower and lender may lead to the rejection of the project. When such a rejection happens, we will suggest possible government interventions which would enable the financing of socially efficient projects which would not be undertaken otherwise because of information asymmetry.

Under asymmetric information, the lender does not know ex ante the type of entrepreneur who asks for a loan. There is a possibility that the entrepreneur will misrep- 
resent his type. Consequently, the lender in his maximization problem has to take into account the borrower's incentive compatibility constraints, which we denote (IC1) and (IC2) in the following formalization of the lender's maximization problem:

\section{PRoblem 1}

$$
\begin{aligned}
\max _{\left(\pi_{1}, R_{1}, \pi_{2}, R_{2}\right)} B & =\theta B_{11}+(1-\theta) B_{22} \\
& =\theta \pi_{1}\left[\delta_{1} R_{1}-\rho\right]+(1-\theta) \pi_{2}\left[\delta_{2} R_{2}-\rho\right]
\end{aligned}
$$

s.t.

$$
\begin{array}{rlrl}
\pi_{i}\left[\delta_{i}\left(y-R_{i}\right)-b_{i}\right] & \geq 0, & \text { (IRi) } \\
\pi_{1}\left[\delta_{1}\left(y-R_{1}\right)-b_{1}\right] & \geq \pi_{2}\left[\delta_{1}\left(y-R_{2}\right)-b_{1}\right], & & \text { IC1 }) \\
\pi_{2}\left[\delta_{2}\left(y-R_{2}\right)-b_{2}\right] & \geq \pi_{1}\left[\delta_{2}\left(y-R_{1}\right)-b_{2}\right], & & \text { (IC2) } \\
& 0 \leq \pi_{i} \leq 1, & \\
& i \in\{1,2\} . &
\end{array}
$$

The optimal contract for the lender under symmetric information shows that the ratio $b_{i} / \delta_{i}$ of opportunity $\operatorname{cost} b_{i}$ and success probability $\delta_{i}$ determines the required repayment for a Type $i$ borrower according to Equation 4. This ratio will also be important for the solution of Problem 1. As we already mentioned in the Introduction, we assume that the success probability $\delta_{i}$ reflects specific human capital of the entrepreneur (skills and knowledge useful primarily for the particular project), while his opportunity cost $b_{i}$ are given by his general human capital (skills and knowledge useful for any activities). According to this interpretation the lower the $b_{i} / \delta_{i}$ ratio, the higher the incentive for the entrepreneur $i$ to undertake the investment project under consideration as opposed to becoming engaged somewhere else with an outside opportunity $b_{i}$.

The solution to Problem 1 is provided in the following Proposition 1.

Proposition 1 The contractual interest factors $R_{i}$ and probabilities of obtaining credit $\pi_{i}, i \in\{1,2\}$, which solve Problem 1 are 


$$
\begin{aligned}
& R_{i}^{*}= \begin{cases}\min \left\{R_{1}^{s}, R_{2}^{s}\right\} & \text { if } \pi_{1}^{*}=\pi_{2}^{*}=1, \\
\max \left\{R_{1}^{s}, R_{2}^{s}\right\} & \text { if } \exists j \mid \pi_{j}^{*}=0 .\end{cases} \\
& \text { If } R_{1}^{s}<R_{2}^{s} \text {, then } \\
& \pi_{1}^{*}=\left\{\begin{array}{l}
1 \quad \text { if } \delta_{1} y-b_{1}-\rho \geq \frac{1-\theta}{\theta} \delta_{2}\left(\frac{b_{1}}{\delta_{1}}-\frac{b_{2}}{\delta_{2}}\right), \\
0 \quad \text { otherwise, }
\end{array}\right. \\
& \pi_{2}^{*}=1 \text {. } \\
& \text { If } R_{1}^{s} \geq R_{2}^{s} \text {, then } \\
& \pi_{1}^{*}=1 \text {, } \\
& \pi_{2}^{*}= \begin{cases}1 & \text { if } \delta_{2} y-b_{2}-\rho \geq \frac{\theta}{1-\theta} \delta_{1}\left(\frac{b_{2}}{\delta_{2}}-\frac{b_{1}}{\delta_{1}}\right), \\
0 & \text { otherwise. }\end{cases}
\end{aligned}
$$

Proof See the Appendix.

Proposition 1 shows that the lender always makes a decision between asking for a lower repayment, which will be accepted by both types of borrower, or requiring higher repayment, which will be accepted only by one type of borrower. From the point of view of standard monopoly theory, this is the usual trade-off faced by a monopolist who is not able to price discriminate. In our model the redlined borrower is always the one with a lower symmetric-information repayment (4). The borrower who is willing to pay the higher repayment and who always obtains the credit is the one with human capital structured more toward the specific human capital, i.e., the one with the lower $b_{i} / \delta_{i}$ ratio.

The redlining of the borrower with a more favorable (from the point of view of the borrower) symmetric-information contract is qualitatively the same result as we would obtain in the perfectly competitive banking market. The intuitive logic behind this outcome is making the more favorable contract, which would be designed for one type of borrower, to be less attractive for the other type of borrower. In the competitive market this would be done by credit rationing (by decreasing the probability of granting an 
attractive contract). In our model with market power of the lender, the lender is either willing to let one of the borrower types get a positive surplus or the lender completely redlines this borrower.

\section{Government Interventions}

The credit rationing of high risk borrowers caused by the informational asymmetry between lender and borrower could be eliminated by government intervention. Government interventions analyzed in this paper operate through the increase of the lender's expected return so that the appropriate credit provision condition in Equation 6 or 9 is satisfied. We consider two different ways of increasing the lender's expected return: credit guarantees and interest rate subsidies. The government support in our model is provided to all applicants without any discrimination. This corresponds to real-life credit support schemes in which all entrepreneurs in a particular line of business (for example in farming) are provided government support as long as a commercial bank is willing to credit a government-supported applicant.

Interest rate subsidy $s$ is paid only in the case of the project's success, as opposed to guarantees, which are paid in the case of failure. While the subsidy reduces the interest rate paid by a borrower, we can treat it analytically just like an exogenous supplement repayment to a lender. The expected profit in Equation 3 is then modified as

$$
B_{i}=\pi_{i}\left[\delta_{i}\left(R_{i}+s\right)-\rho\right] .
$$

Under the guarantee program the government guarantees the payment of an exogenously chosen amount $g$ in the case of zero return from the project. In practice this guarantee amount is determined as a given percentage of the loan principal, which is equal to 1 under our normalization. The lender's expected profit in Equation 3 is 
modified as

$$
B_{i}=\pi_{i}\left[\delta_{i} R_{i}+\left(1-\delta_{i}\right) g-\rho\right] .
$$

The expected utility of a borrower, under both types of interventions, is still given by Equation 2 since the interventions influence the borrower's utility only indirectly through their impact on the lender's profit.

The main idea behind government interventions analyzed in this section is to decrease the critical level of the expected return required by a lender in order to provide loans to borrowers with a lower interest repayment in the case of symmetric information. The optimal level of government support equates this critical level with the symmetric information state so that all socially efficient projects are undertaken. This intervention mechanism is similar to price subsidies which are used in standard monopoly regulation theory to induce the monopolist to produce a socially optimal quantity of his product. In our model, guarantees and interest rate subsidies play the role of price subsidies that compensate the monopolist for lost profits on the volume of production he would otherwise be selling with higher prices.

In the following subsections we implement this general approach in the analysis of credit market equilibrium and the government budget impact of credit guarantees and interest rate subsidies.

\subsection{Credit Guarantees}

As long as the government guarantees the payment of an exogenously determined amount $g$ in the case of zero return from a project, the maximization problem of the lender under this intervention is as follows:

\section{Problem 2}

$$
\begin{aligned}
\max _{\left(\pi_{1}, R_{1}, \pi_{2}, R_{2}\right)} B & =\theta B_{11}+(1-\theta) B_{22} \\
& =\theta \pi_{1}\left[\delta_{1} R_{1}+\left(1-\delta_{1}\right) g-\rho\right]+(1-\theta) \pi_{2}\left[\delta_{2} R_{2}+\left(1-\delta_{2}\right) g-\rho\right],
\end{aligned}
$$


subject to the same conditions as in the case without an intervention.

The solution to this problem is provided in the following proposition:

Proposition 2 The credit contract with credit guarantees that solves Problem 2 is

If $R_{1}^{s}<R_{2}^{s}$ then

$$
R_{i}^{*}= \begin{cases}\min \left\{R_{1}^{s}, R_{2}^{s}\right\} & \text { if } \pi_{1}^{*}=\pi_{2}^{*}=1, \\ \max \left\{R_{1}^{s}, R_{2}^{s}\right\} & \text { if } \exists j \mid \pi_{j}^{*}=0 .\end{cases}
$$

$$
\begin{aligned}
& \pi_{1}^{*}= \begin{cases}1 & \text { if } \delta_{1} y-b_{1}-\rho \geq \frac{1-\theta}{\theta}\left(\frac{b_{1}}{\delta_{1}}-\frac{b_{2}}{\delta_{2}}\right) \delta_{2}-\left(1-\delta_{1}\right) g, \\
0 & \text { otherwise, }\end{cases} \\
& \pi_{2}^{*}=1 .
\end{aligned}
$$

If $R_{1}^{s} \geq R_{2}^{s}$ then

$$
\begin{aligned}
& \pi_{1}^{*}=1, \\
& \pi_{2}^{*}= \begin{cases}1 & \text { if } \delta_{2} y-b_{2}-\rho \geq \frac{\theta}{1-\theta} \delta_{1}\left(\frac{b_{2}}{\delta_{2}}-\frac{b_{1}}{\delta_{1}}\right)-\left(1-\delta_{2}\right) g, \\
0 & \text { otherwise. }\end{cases}
\end{aligned}
$$

Proof See the Appendix.

For $g=0$, we obtain the same result as in the case without intervention and Condition 14 for the case $R_{1}^{s}<R_{2}^{s}$ will be identical to the corresponding Condition 6 in the case without government intervention. The term $\left(1-\delta_{1}\right) g$, by which these two conditions differ when a positive guarantee is provided, expresses incremental expected payoff to the lender per each high-risk borrower to whom he would extend additional credit as a result of a government guarantee. Similarly this occurs in the case $R_{1}^{s} \geq R_{2}^{s}$.

The effect of credit guarantees on the cut-off value of social surplus determining the redlining of a high-risk borrower is nonambiguous, and it is immediately obvious. Taking the derivative of the right hand side of Condition 14 with respect to $g$, which is equal to $\left(\delta_{1}-1\right)$, we see that an increase in a guarantee increases the chance that a loan to a high-risk borrower will be granted for sure. Solving the inequality in Condition 14 as 
an equation provides the smallest value $g$ for which loans to a high-risk borrower will be always granted with the probability of $\pi_{1}^{*}=1$ :

$$
g=\frac{\frac{1-\theta}{\theta} \delta_{2}\left(\frac{b_{1}}{\delta_{1}}-\frac{b_{2}}{\delta_{2}}\right)-\left(\delta_{1} y-b_{1}-\rho\right)}{1-\delta_{1}} .
$$

The provision of a higher guarantee than the one in Equation 18 would just amount to a wealth transfer toward the lender without any impact on social efficiency. Any guarantee lower than Expression 18 would lead to an unjustified use of public money since such a low guarantee would not provide sufficient incentive for the lender to decrease the required interest rate payment to the symmetric information interest rate of a highrisk borrower $y-b_{1} / \delta_{1}$. With too low a guarantee the lender would keep charging a high interest rate accessible only to low-risk borrowers; high-risk borrowers would be still redlined and the lender would increase his expected profit.

A similar analysis applies to the case of removing possible redlining of low-risk borrower when $R_{1}^{s} \geq R_{2}^{s}$.

\subsection{Interest Rate Subsidies}

The provision of interest rate subsidies most directly addresses the basic mechanism leading to credit rationing. Credit rationing appears when the lender obtains a higher profit by charging a high interest rate, which drives part of the borrowers' population out of the market, rather than by charging a lower interest rate acceptable to all borrowers. Since the interest rate subsidy directly increases the return to the lender on each loan provided without imposing any costs on the borrower, the lender is better off by accepting all credit applications than by rejecting some of them as long as the credit subsidy is sufficiently high. When a sufficiently high interest rate subsidy is available, the lender does not have any incentive to increase the interest rate (and to loose some clients) because he receives the interest rate subsidy anyway and he keeps all of the clients.

The maximization problem of the lender under the interest rate subsidies is given by 


\section{PROBLEM 3}

$$
\begin{aligned}
\max _{\left(\pi_{1}, R_{1}, \pi_{2}, R_{2}\right)} B & =\theta B_{11}+(1-\theta) B_{22} \\
& =\theta \pi_{1}\left[\delta_{1}\left(R_{1}+s\right)-\rho\right]+(1-\theta) \pi_{2}\left[\delta_{2}\left(R_{2}+s\right)-\rho\right],
\end{aligned}
$$

s.t. the same conditions as in the case without an intervention.

The subsidy is paid only in the case of the project's success, as opposed to guarantees which are paid in the case of failure. The subsidy is just an exogenous supplement to a repayment to the lender, and it does not enter into the (IC) and (IR) constraints of a borrower.

Proposition 3 The credit contract with interest rate subsidies which solves Problem 3 is

$$
R_{i}^{*}= \begin{cases}\min \left\{R_{1}^{s}, R_{2}^{s}\right\} & \text { if } \pi_{1}^{*}=\pi_{2}^{*}=1, \\ \max \left\{R_{1}^{s}, R_{2}^{s}\right\} & \text { if } \exists j \mid \pi_{j}^{*}=0 .\end{cases}
$$

If $R_{1}^{s}<R_{2}^{s}$ then

$$
\begin{aligned}
& \pi_{1}^{*}= \begin{cases}1 & \text { if } \delta_{1} y-b_{1}-\rho \geq \frac{1-\theta}{\theta}\left(\frac{b_{1}}{\delta_{1}}-\frac{b_{2}}{\delta_{2}}\right) \delta_{2}-\delta_{1} s, \\
0 \quad \text { otherwise, }\end{cases} \\
& \pi_{2}^{*}=1 \text {. } \\
& \text { If } R_{1}^{s} \geq R_{2}^{s} \text { then }
\end{aligned}
$$

Proof See the Appendix.

In the same way as in the cases of guarantees, we obtain the same result as in the credit market without intervention if $s=0$. Taking the derivative of the right-hand side of Equation 21 with respect to $s$, which is equal to $\left(-\delta_{1}\right)$, we immediately see that an increase in interest payment subsidies increases the chance that a loan to a high-risk 
borrower will be granted for sure. Solving the inequality in Expression 21 as an equation provides the smallest value $s$ for which credit rationing of a high-risk borrower will be eliminated:

$$
s=\frac{\frac{1-\theta}{\theta} \delta_{2}\left(\frac{b_{1}}{\delta_{1}}-\frac{b_{2}}{\delta_{2}}\right)-\left(\delta_{1} y-b_{1}-\rho\right)}{\delta_{1}} .
$$

Similarly to the case of guarantees, the expected value $\theta \delta_{1} s$ of the subsidies provided to all high-risk borrowers who would be redlined in the absence of government intervention is exactly equal to the wedge between informational rent for low-risk borrowers $(1-\theta) \delta_{2}\left(b_{1} / \delta_{1}-b_{2} / \delta_{2}\right)$ and the social surplus $\theta\left(\delta_{1} y-b_{1}-\rho\right)$ associated with the redlined high-risk projects.

A similar analysis applies to the case of removing possible redlining of a low-risk borrower when $R_{1}^{s} \geq R_{2}^{s}$.

\subsection{Government Budget Impact of Interventions}

In order to compare the government budget impact of both types of interventions, we consider such values $G_{s}$ and $G_{g}$ of subsidies $s$ and guarantees $g$ which make sure that a loan to a Type 1 borrower will be always granted for sure. We will first evaluate the budget cost for the case when symmetric information repayment of a Type 1 borrower is lower than that for a Type 2 borrower. From Equation 19, we get the expected budget cost of government subsidies:

$$
G_{s}=\theta \delta_{1} s+(1-\theta) \delta_{2} s=s\left[\theta \delta_{1}+(1-\theta) \delta_{2}\right]
$$

The expected budget cost $G_{s}$ is computed as the optimal size of subsidy $s$ weighted by a population-wide average probability of success.

From Equation 12, we get the expected budget cost of credit guarantees:

$$
G_{g}=\theta\left(1-\delta_{1}\right) g+(1-\theta)\left(1-\delta_{2}\right) g=g\left\{1-\left[\theta \delta_{1}+(1-\theta) \delta_{2}\right]\right\} .
$$


The expected budget cost $G_{g}$ is given as the optimal size of guarantee $g$ weighted by the population-wide average probability of invoking the guarantee.

The comparison of the budget costs of subsidies and guarantees shows that

$$
G_{s}-G_{g}=\theta\left[\delta_{1} s-\left(1-\delta_{1}\right) g\right]+(1-\theta)\left[\delta_{2} s-\left(1-\delta_{2}\right) g\right]
$$

Substitution for $g$ from Equation 18 and for $s$ from Equation 25 shows that the expression in the first square brackets on the right hand side of Equation 28 vanishes. Since $\delta_{2}>\delta_{1}$, this also implies that the expression in the second square brackets on the right-hand side of Equation 28 is positive. Therefore $G_{s}-G_{g}>0$, which means that guarantees are a cheaper form of intervention than interest rate subsidies.

When we compare the expected budget cost of subsidies and guarantees, we have to keep in mind that the absolute size of the funding gap which has to be transferred to the lender in order to entice him to provide credit under terms affordable for the high-risk borrower is the same in both cases. What is different are the ways in which this sum is transferred. The absolute value of monetary transfer required for making the loan to the (otherwise redlined) Type 1 borrower sufficiently attractive to the lender is the same for subsidies and guarantees. The difference in government costs is therefore caused by the provision of government support to a Type 2 borrower who is observationally indistinguishable from a Type 1 borrower. This subsidy to Type 2 borrowers is provided in the case of success; therefore, the expected value of this subsidy is bigger than the expected value of the subsidy provided to Type 1 borrowers. On the contrary, the expected value of the guarantee provided to Type 2 borrowers is lower than the expected value of the guarantee provided to Type 1 borrowers. Therefore the guarantee has to be cheaper for the government.

This comparison between subsidies and guarantees is summarized in the following proposition.

Proposition 4 Assume that the borrower with a lower chance of success is redlined. Then, from the point of view of government budget costs, the use of guarantees is a 
cheaper way to achieve the realization of all projects with a positive net present value than the use of subsidies.

The major intuitive argument often used by policy makers in favor of guarantees is that guarantees lead to government budget expenses only in the case of a project's failure while the subsidies have to be paid for all successful projects (see discussion of myopic politicians provided by HONOHAN [2010]). This argument implicitly assumes that probabilities of success $\delta_{i}$ are sufficiently high, and therefore the guarantees have to be cheaper than subsidies. Our results presented in Proposition 4 show that in the case of alleviating redlining of a borrower with a lower chance of success guarantees are actually cheaper even in the case of low probabilities of success.

From the point of view of a lender, the ordering of the desirability of different forms of government interventions is exactly reversed since the lender prefers the highest possible transfers from the government.

Now we comparise budget cost of subsidies and guarantees for the case when the symmetric information repayment is lower for a Type 2 borrower:

$$
G_{g}-G_{s}=\theta\left[\left(1-\delta_{1}\right) g-\delta_{1} s\right]+(1-\theta)\left[\left(1-\delta_{2}\right) g-\delta_{2} s\right]
$$

Because $\left(1-\delta_{2}\right) g-\delta_{2} s=0$ and $\delta_{2}>\delta_{1}$, we conclude that in this case the ordering of budget costs required to remove the redlining of low-risk borrowers is $G_{g}>G_{s}$. This result is presented in the following proposition.

Proposition 5 Assume that the borrower with a higher chance of success is redlined. Then, from the point of view of government budget costs, the use of subsidies is a cheaper way to achieve the realization of all projects with a positive net present value than the use of guarantees.

The comparison of Propositions 4 and 5 shows that the budget impact ranking of subsidies and guarantees is different for cases when the borrower with higher or lower chances of success is redlined. This is caused by different types of entrepreneurs having 
a less specific structure of their human capital, which may lead to their redlining in each case. In one case the redlined borrower is a Type 2 entrepreneur who is not willing to pay a high interest rate on loans because his high general human capital provides him with good outside alternative opportunities. The government support for otherwise redlined Type 2 entrepreneurs will entail the same expected cost both for guarantees and interest rate subsidies. This means that the cost difference will be caused by providing the guarantees or subsidies to Type 1 entrepreneurs. Since the value of subsidy per borrower has to be the same for all borrowers, the difference in expected costs of subsidies is driven by the probability of their provision. This probability is lower for a Type 1 borrower than for a Type 2 borrower. Therefore the expected cost of an interest rate subsidy for a Type 1 borrower will be lower than for a Type 2 borrower. A similar argument shows that on the contrary the expected cost of the guarantee will be higher for a Type 1 entrepreneur than for a Type 2 entrepreneur.

\subsection{Economic Policy Considerations}

Possible recommendations on the use of different forms of government support are usually based on the assumption that the government chooses forms of support such that governmental monetary outlays are minimized. If we admit the possibility that the political influence of lenders is strong enough to ensure that government intervention programs are biased toward providing high transfers to banks, then the situation is reversed. Under this different political economy scenario we should expect credit guarantees to be prevalent in the case of redlining the borrower with higher probability of success and credit subsidies to be prevalent in the case when the redlined borrower is the one with lower chances of success.

Channeling the government funds through commercial lending instead of direct provision of subsidies to firms is often considered to be a generally accepted practice. The firm owners may prefer to receive lump-sum payments in the form of direct government 
subsidies, but they realize that tying government support with commercial loans may actually make more funds available for the firm. Additionally the entrepreneurs realize that the provision of indirect support through credit guarantees and subsidies to commercially extended credit is easier to accept by the general public and for policymakers rather than asking for direct support from public funds.

The danger of government support channeled through the lender with market power could be that the lender may adjust the terms of lending such that all benefits would accrue to him and the borrower would not be better off after the intervention. Our model shows that this situation will not happen with credit guarantees and interest rate subsidies. Since all the borrowers will be strictly better off, this type of intervention is universally acceptable for politicians, voters and civil servants. The widespread acceptance of this type of support also means that it would be difficult to remove unless a different form of support is offered to replace it. As an example of successful downsizing, we could mention the importance of commercial credit guarantees and interest rates subsidies provided to farmers in the Czech Republic since 1994 by the Supporting and Guarantee Agricultural and Forestry Fund. This very successful program was responsible for a significant part of Czech government expenditures on agriculture policy in the second half of the 1990s, but its funding significantly diminished with the gradual incorporation of the Common Agricultural Policy (CAP) of the EU. Czech farmers and agricultural policymakers were willing to sacrifice public funding for commercial credit support in return for higher payments from the EU and Czech public funds in the framework of the CAP.

\section{Extension to Competitive Credit Markets}

In this section we provide an extension of our model to the competitive market structure. As opposed to the monopolistic lender considered in the previous sections, now we consider the situation with many lenders engaged in Bertrand competition. To keep 
this extension section brief we do not provide the proofs here; we only briefly state the solutions of the model under both types of government interventions considered in this paper. We will also concentrate only on the situation when the values of the reservation utilities and likelihood of success parameters are such that $\frac{b_{2}}{b_{1}} \geq \frac{\delta_{2}}{\delta_{1}}$. That is, we consider the setting when the borrower with lower symmetric information repayment is a Type 2 borrower.

The lender under asymmetric information does not know ex ante the risk class of a borrower. Because of the competition from other lenders, each lender attempts to offer to each type of borrower the best conditions possible. In the absence of government intervention, the information asymmetry between lenders (who do not know the type of borrower) and the borrowers leads to the credit rationing of the Type 2 borrower. This is similar to the market structure with a monopolistic lender, where also the Type 2 borrower is rationed. The difference is that under market power of the lender, the Type 2 borrower is redlined (rejected the credit with probability 1) while with a competitive market structure the equilibrium credit rationing probability is a number between zero and one. This credit rationing may be alleviated by government intervention.

If the guarantees are provided, the maximization problem of a lender is given by

$$
\begin{aligned}
\max _{\left(\begin{array}{c}
\pi_{1}, R_{1} \\
\pi_{2}, R_{2}
\end{array}\right) M=} & \theta U_{11}+(1-\theta) U_{22} \\
= & \theta \pi_{1}\left[\delta_{1}\left(y-R_{1}\right)-b_{1}\right]+ \\
& (1-\theta) \pi_{2}\left[\delta_{2}\left(y-R_{2}\right)-b_{2}\right]
\end{aligned}
$$

s.t.

$$
\begin{aligned}
\pi_{1}\left[\delta_{1}\left(y-R_{1}\right)-b_{1}\right] & \geq \pi_{2}\left[\delta_{1}\left(y-R_{2}\right)-b_{1}\right], \\
\pi_{2}\left[\delta_{2}\left(y-R_{2}\right)-b_{2}\right] & \geq \pi_{1}\left[\delta_{2}\left(y-R_{1}\right)-b_{2}\right], \\
U_{i i} & \geq 0, \\
0 & \leq \pi_{i} \leq 1,
\end{aligned}
$$




$$
\begin{aligned}
\delta_{i} R_{i}+\left(1-\delta_{i}\right) g-\rho & =0 \\
i & \in\{1,2\} .
\end{aligned}
$$

Equation (29) is a zero profit condition for lenders, which explicitly prohibits crosssubsidization. This means that it is not possible for lenders to suffer a loss on a contract to one type of borrower and to enjoy a positive profit on a contract to another type of borrower. The zero profit constraint puts a bound on the ability of the lender to offer the most attractive contract to the borrower when the lender competes for him with the other lenders.

The solution of this problem are two different contracts $\left(\pi_{i}^{*}, R_{i}^{*}\right)$, one offered to the high-risk borrower and one to the low-risk borrower.

When the interest rate subsidies are used, the lender's zero profit condition (29) is replaced by

$$
\delta_{i}\left(R_{i}+s\right)-\rho=0
$$

For the government support realized through guarantees, the contracts for a high-risk (indexed as borrower 1) and low risk borrower (indexed as borrower 2) are given by

$$
\begin{gathered}
\pi_{1}^{*}=1, R_{i}^{*}=\frac{\rho-\left(1-\delta_{i}\right) g}{\delta_{i}}, \quad i \in\{1,2\} . \\
\pi_{2}^{*}=\frac{\delta_{1} y-\rho-b_{1}+\left(1-\delta_{1}\right) g}{\delta_{1} y-\frac{\delta_{1}}{\delta_{2}} \rho-b_{1}+\frac{\delta_{1}\left(1-\delta_{2}\right)}{\delta_{2}} g} .
\end{gathered}
$$

For government support realized through interest rates subsidies, the contracts for a high-risk (indexed as borrower 1) and low risk borrower (indexed as borrower 2) are given by

$$
\begin{gathered}
\pi_{1}^{*}=1, R_{i}^{*}=\frac{\rho}{\delta_{i}}-s, \quad i \in\{1,2\} . \\
\pi_{2}^{*}=\frac{\delta_{1} y-\rho-b_{1}+\delta_{1} s}{\delta_{1} y-\frac{\delta_{1}}{\delta_{2}} \rho-b_{1}+\delta_{1} s} .
\end{gathered}
$$


Our solutions show that as opposed to the monopolistic market structure, where meaningful government intervention exactly removes the gap required to remove redlining of the Type 2 borrower, the government facing a competitive credit market may choose the level of its intervention according to how much it wants to decrease the level of credit rationing.

In the remainder of this section we will use these equilibrium values of the required repayments $R_{i}^{*}$ and credit rationing probabilities $\pi_{i}^{*}, i \in\{1,2\}$ to evaluate the budget cost of different types of interventions.

The expected budget cost of different forms of government interventions $G_{m}, m \in$ $\{g, s\}$ are given by the following formulas:

\section{Guarantees}

$$
G_{g}=\theta \pi_{1}^{*}\left(1-\delta_{1}\right) g+(1-\theta) \pi_{2}^{*}\left(1-\delta_{2}\right) g
$$

Interest rate subsidies

$$
G_{s}=\theta \pi_{1}^{*} \delta_{1} s+(1-\theta) \pi_{2}^{*} \delta_{2} s
$$

The values of guarantees and subsidies are

$$
\begin{gathered}
g\left(\pi_{h}\right)=\frac{\delta_{2}\left[\pi_{h}\left(\delta_{1} y-\frac{\delta_{1}}{\delta_{2}} \rho-b_{1}\right)-\left(\delta_{1} y-\rho-b_{1}\right)\right]}{\left(1-\delta_{1}\right) \delta_{2}-\pi_{h} \delta_{1}\left(1-\delta_{2}\right)} . \\
s\left(\pi_{h}\right)=\frac{\pi_{h}\left(\delta_{1} y-\frac{\delta_{1}}{\delta_{2}} \rho-b_{1}\right)-\left(\delta_{1} y-\rho-b_{1}\right)}{\delta_{1}\left(1-\pi_{h}\right)} .
\end{gathered}
$$

The comparison of the cost of guarantees and interest rate subsidies shows that:

$$
\begin{aligned}
G_{s}- & G_{g}=\left[\pi_{h}\left(\delta_{1} y-\frac{\delta_{1}}{\delta_{2}} \rho-b_{1}\right)-\left(\delta_{1} y-\rho-b_{1}\right)\right] . \\
& \frac{\left[\delta_{2}\left(1-\delta_{1}\right)-\pi_{h} \delta_{1}\left(1-\delta_{2}\right)\right]\left[\theta \delta_{1}+(1-\theta) \delta_{2} \pi_{h}\right]-\delta_{1} \delta_{2}\left(1-\pi_{h}\right)\left[\theta\left(1-\delta_{1}\right)+(1-\theta) \pi_{h}\left(1-\delta_{2}\right)\right]}{\delta_{1}\left(1-\pi_{h}\right)\left[\delta_{2}\left(1-\delta_{1}\right)-\pi_{h} \delta_{1}\left(1-\delta_{2}\right)\right]} \\
= & {\left[\pi_{h}\left(\delta_{1} y-\frac{\delta_{1}}{\delta_{2}} \rho-b_{1}\right)-\left(\delta_{1} y-\rho-b_{1}\right)\right] \frac{\left(\delta_{2}-\delta_{1}\right) \pi_{h}\left[\delta_{1} \theta+\delta_{2}(1-\theta)\right]}{\left(1-\pi_{h}\right)\left[\delta_{2}\left(1-\delta_{1}\right)-\pi_{h} \delta_{1}\left(1-\delta_{2}\right)\right]} . }
\end{aligned}
$$


Since the denominator term $\left(1-\pi_{h}\right)\left[\delta_{2}\left(1-\delta_{1}\right)-\pi_{h} \delta_{1}\left(1-\delta_{2}\right)\right]$ may be shown to be positive, the entire fraction is positive. The sign of the difference $\left(G_{s}-G_{g}\right)$ therefore depends on the leading term $\left[\pi_{h}\left(\delta_{1} y-\frac{\delta_{1}}{\delta_{2}} \rho-b_{1}\right)-\left(\delta_{1} y-\rho-b_{1}\right)\right]$, which is positive if $\pi_{h}>\frac{\delta_{1} y-\rho-b_{1}}{\delta_{1} y-\frac{\delta_{1}}{\delta_{2}} \rho-b_{1}}$. This fraction is equal to the size of credit rationing in the absence of government intervention. Since in our model any meaningful intervention leads to a decrease in the credit ration (meaning a increase in $\pi_{h}$ ), the leading term and the whole expression will be positive. Therefore $\left(G_{s}-G_{g}\right)>0$. This argument also confirms that the formulas for interventions $g\left(\pi_{h}\right)$ and $s\left(\pi_{h}\right)$ derived in this section take only positive values. The result that the interest rate subsidies are more expensive than the guarantees means that the budget cost minimizing government unambiguously prefers guarantees to interest rate subsidies. This is in sharp contrast to the monopolistic market structure where the budget-cost-minimizing government would choose interest rate subsidies.

\section{Conclusions}

This paper presents a policy-relevant model of government interventions in credit markets. It proves that both considered instruments (government credit guarantees and interest rate subsidies) have nonambiguous positive effects on social efficiency. Both enable the government to ensure that all socially efficient projects will be undertaken. The principal difference between these two instruments is in their budgetary implications, which are quite different depending on which type of borrower is rationed. The expected size of the monetary transfer from government to lenders with market power is lower for credit guarantees in the case that a borrower with lower probability of success is rationed in the absence of government intervention. It is lower for interest rate subsidies if the rationed borrower has higher chances for success.

This means that as long as the participation cost of low-risk entrepreneurs are sufficiently close to the participation cost of high-risk entrepreneurs, the budget-costminimizing government facing the lenders with market power should prefer guarantees 
over interest rate subsidies as an intervention instrument for the elimination of credit rationing in a targeted credit market segment. Our results show that relaxing the usuallymaintained modeling assumption of uniform participation costs for all borrowers does not eliminate the theoretical argument for the desirability of government support. However, it has an effect on the choice of the most cost-efficient form of this support when the difference in participation costs is sufficiently high.

The result that the optimal choice of government intervention instrument is not uniform but depends on the parametrization of the problem shows that we have to be cautious in forming policy conclusions based on this model. This is also emphasized by considering the relaxation of the lender's market power assumption. A change in market structure from monopolistic to competitive leads to the reversal of budget cost comparisons between the two considered forms of intervention. Therefore a clear policy recommendation following from our model is that government interventions in the form of credit guarantees or interest rate subsidies are helpful, but the decision which one of these two forms of interventions is better is quite subtle.

Government intervention is always favorable both for redlined and financed types of entrepreneurs in our model. The entrepreneur who would be credit rationed in the absence of government support would be able to run his project, and the other type of entrepreneur will receive better contract conditions than would be the case in the absence of government intervention. Each type of borrower is made better off by government intervention in the case when the other type of borrower would be redlined since the induced pooling means that he gets to keep a positive surplus as compared to only breaking even under a separating equilibrium.

As our model shows, public support of the commercial credit provision is beneficial for all borrowers and lenders. This may explain the widespread use of these programs and their favorable treatment by policymakers, financiers and businessmen. The lenders not only appreciate the possibility to extend the guaranteed credit, but they also benefit 
from the positive effect of government guarantees on their regulatory capital (TEPLY $[2007])$.

The credit guarantees and subsidies provided by government to all applicants who passed the credit screening process by the commercial bank are potentially very strong policy instruments. Our model shows that they are also efficient instruments as long as the forms of credit support are chosen in the right way. The policy relevance of our model is obvious from the fact that the model is based on the basic features of a number of successful credit support programs all over the world. The introduction of the credit support program is especially beneficial in the time of a credit crunch at the sectoral level, as has happened in agriculture and other restructured industries in many transition economies in the 1990s, or on an economy-wide level, which was the case in Japan during 1998-2001.

The public support of commercially granted credit does not exhibit the squeeze-out effect on commercial loans which may be caused by the direct governmental provision of soft loans. Nevertheless, there are still two contradictory effects of this type of public intervention. The positive effect is alleviating the credit crunch and enabling banks to finance potentially profitable business projects that would not be financed otherwise. The negative effect could be connected with adverse selection and moral hazard problems associated with subsidized lending, which we did not consider in this paper. There could be adverse selection where companies with low profitability and socially inefficient projects would use the public support program. Or there could be a significant moral hazard on the side of banks that would not exercise the due screening of loan applicants and would not provide proper monitoring of the approved loans. The experience of both transition economies with sectoral credit support programs analyzed by JANDA [2008] and the Japanese economy-wide program open to all small and medium-sized enterprises (SME) that was analyzed by Fukanuma, Nemoto, and Watanabe [2006], and Uesugi, Sakai, And Yamashiro [2006], and Uesugi [2008] show that the positive 
effects prevailed and credit support programs had a positive impact on the economy.

\section{Appendix}

\section{A.1 Proof of Proposition 1}

First, we consider the case of lower symmetric information repayment of a Type 1 borrower. From (IC2) we get

$$
\begin{aligned}
\pi_{2}\left[\delta_{2}\left(y-R_{2}\right)-b_{2}\right] & \geq \pi_{1}\left[\delta_{2}\left(y-R_{1}\right)-b_{2}\right] \\
& >\frac{\delta_{1}}{\delta_{2}} \pi_{1}\left[\delta_{2}\left(y-R_{1}\right)-b_{2}\right] \\
& =\pi_{1}\left[\delta_{1}\left(y-R_{1}\right)-\frac{\delta_{1}}{\delta_{2}} b_{2}\right] \\
& >\pi_{1}\left[\delta_{1}\left(y-R_{1}\right)-b_{1}\right]
\end{aligned}
$$

where the last inequality is due to the condition $\delta_{2} / \delta_{1}>b_{2} / b_{1}$, which is equivalent to lower symmetric repayment of a Type 1 borrower. The strict inequalities change to equalities for $\pi_{1}=0$. This means that as long as (IR1) is satisfied, (IR2) is satisfied, too. Since (IR2) is slack for all positive $\pi_{1}$, we obtain $\pi_{2}>0$ in this case. Because zero probabilities of granting credit to both types of borrowers would lead to a no-lending situation, we further consider the situation when at least one of $\pi_{1}$ and $\pi_{2}$ is positive.

In the following Lagrangian for Problem 1 we assume that the (IC1) is satisfied. Once we solve for the optimal interest rates and probabilities of providing credit, we show that these values satisfy (IC1). Under this assumption the Lagrangian is

$$
\begin{aligned}
L= & \theta \pi_{1}\left[\delta_{1} R_{1}-\rho\right]+(1-\theta) \pi_{2}\left[\delta_{2} R_{2}-\rho\right]+\lambda \pi_{1}\left[\delta_{1}\left(y-R_{1}\right)-b_{1}\right]+ \\
& \mu\left\{\pi_{2}\left[\delta_{2}\left(y-R_{2}\right)-b_{2}\right]-\pi_{1}\left[\delta_{2}\left(y-R_{1}\right)-b_{2}\right]\right\}+\tau_{1} \pi_{1}+\tau_{2}\left(1-\pi_{1}\right)+\tau_{3} \pi_{2}+\tau_{4}\left(1-\pi_{2}\right) .
\end{aligned}
$$


The Kuhn-Tucker conditions for this problem are given by FOC

$$
\begin{aligned}
\frac{\partial L}{\partial R_{1}} & =\theta \pi_{1} \delta_{1}-\lambda \pi_{1} \delta_{1}+\mu \pi_{1} \delta_{2}=0, \\
\frac{\partial L}{\partial R_{2}} & =(1-\theta) \pi_{2} \delta_{2}-\mu \pi_{2} \delta_{2}=0, \\
\frac{\partial L}{\partial \pi_{1}} & =\theta\left(\delta_{1} R_{1}-\rho\right)+\lambda\left[\delta_{1}\left(y-R_{1}\right)-b_{1}\right]-\mu\left[\delta_{2}\left(y-R_{1}\right)-b_{2}\right]+\tau_{1}-\tau_{2}=0, \\
\frac{\partial L}{\partial \pi_{2}} & =(1-\theta)\left(\delta_{2} R_{2}-\rho\right)+\mu\left[\delta_{2}\left(y-R_{2}\right)-b_{2}\right]+\tau_{3}-\tau_{4}=0,
\end{aligned}
$$

and by (IC2), (IR1), $0 \leq \pi_{1} \leq 1,0 \leq \pi_{2} \leq 1$, complementary slackness conditions, and the non-negativity of multipliers.

Suppose that (IR1) is not binding. Complementary slackness then implies $\partial L / \partial R_{1}=$ $\pi_{1}\left(\theta \delta_{1}+\mu \delta_{2}\right)=0 \Rightarrow \pi_{1}=0$. This leads to a contradiction with (IR1) not binding. Therefore (IR1) has to bind. This means that $\pi_{1}^{*}=0$ or $R_{1}^{*}=y-b_{1} / \delta_{1}$. Since $\pi_{2}>0$ for all $\pi_{1}>0$, the positive value of the multiplier $\mu=1-\theta$ which we obtain from $\partial L / \partial R_{2}=0$ shows that (IC2) is also binding.

After substituting $\mu=1-\theta$ into $\partial L / \partial \pi_{2}$ we obtain

$$
\frac{\partial L}{\partial \pi_{2}}=(1-\theta)\left(\delta_{2} y-\rho-b_{2}\right)+\tau_{3}-\tau_{4}=0
$$

Since $\delta_{2} y-\rho-b_{2}>0$ by our Assumption 1 of positive net present value, $\tau_{4}$ has to be positive. Therefore by complementary slackness, $\pi_{2}^{*}=1$.

Since $\pi_{2}^{*}=1$, the binding constraint (IC2) implies that

$$
R_{2}^{*}=y-\frac{b_{2}}{\delta_{2}}+\pi_{1}\left(\frac{b_{2}}{\delta_{2}}-\frac{b_{1}}{\delta_{1}}\right)
$$

Assume $\pi_{1}>0$. Then $\partial L / \partial R_{1}=0$ implies that $\lambda=\left[\theta \delta_{1}+(1-\theta) \delta_{2}\right] / \delta_{1}$. After substitutions for $R_{1}, \lambda, \mu$ into $\partial L / \partial \pi_{1}$, we obtain

$$
\frac{\partial L}{\partial \pi_{1}}=\theta\left(\delta_{1} y-b_{1}-\rho\right)+(1-\theta) \delta_{2}\left(\frac{b_{2}}{\delta_{2}}-\frac{b_{1}}{\delta_{1}}\right)-\tau_{2}=0 .
$$

As long as

$$
\delta_{1} y-b_{1}-\rho \geq \frac{1-\theta}{\theta} \delta_{2}\left(\frac{b_{1}}{\delta_{1}}-\frac{b_{2}}{\delta_{2}}\right)
$$


we obtain $\pi_{1}^{*}=1$ as an optimal solution.

To check that the solution satisfies (IC1), we first substitute the values of $R_{i}^{*}$ for $\pi_{i}^{*}=1$ into (IC1). This simplifies as $0 \geq 0$, which means that (IC1) will be satisfied. Then we substitute the values of $R_{i}^{*}$ for $\pi_{1}^{*}=0, \pi_{2}^{*}=1$ into (IC1). In that case, (IC1) simplifies as $b_{1} / \delta_{1} \geq b_{2} / \delta_{2}$, which is by definition always true in the case with lower symmetric information repayment of a Type 1 borrower.

By this we proved the part of Proposition 1 dealing with the case of lower symmetric information repayment of a Type 1 borrower. Now we finish the proof with the case of lower symmetric information repayment of a Type 2 borrower. Firstly we get from (IC1)

$$
\begin{aligned}
\pi_{1}\left[\delta_{1}\left(y-R_{1}\right)-b_{1}\right] & \geq \pi_{2}\left[\delta_{1}\left(y-R_{2}\right)-b_{1}\right] \\
& \geq \pi_{2}\left[\delta_{1}\left(y-R_{2}\right)-b_{2} \frac{\delta_{1}}{\delta_{2}}\right] \\
& >\delta_{1} \pi_{2}\left[\delta_{2}\left(y-R_{2}\right)-b_{2}\right.
\end{aligned}
$$

where the inequality in the second line follows from the definition of this case. As long as $\pi_{2}\left[\delta_{2}\left(y-R_{2}\right)-b_{2}\right] \geq 0$, we obtain that $\delta_{1} \pi_{2}\left[\delta_{2}\left(y-R_{2}\right)-b_{2}\right] \geq 0$ and (IR1) is satisfied as a non-binding restriction for all positive $\pi_{2}$, which leads to $\pi_{1}>0$.

Going through the same steps as in the previous case, we find that

$$
\begin{aligned}
& \pi_{1}^{*}=1, \\
& R_{2}^{*}=y-\frac{b_{2}}{\delta_{2}} \quad \text { if } \pi_{2}^{*}>0 \\
& R_{1}^{*}=y-\frac{b_{1}}{\delta_{1}}+\pi_{2}\left(\frac{b_{1}}{\delta_{1}}-\frac{b_{2}}{\delta_{2}}\right) .
\end{aligned}
$$

Similarly to the previous case we obtain

$$
\pi_{2}^{*}= \begin{cases}1 & \text { if } \delta_{2} y-b_{2}-\rho \geq \frac{\theta}{1-\theta} \delta_{1}\left(\frac{b_{2}}{\delta_{2}}-\frac{b_{1}}{\delta_{1}}\right) \\ 0 & \text { otherwise. }\end{cases}
$$

Q.E.D. 


\section{A.2 Proof of Proposition 2}

We follow the strategy used in the case without an intervention. We will consider here the case of lower symmetric information repayment of Type 1 borrower. In the same way as in the non-intervention situation, we eliminate (IR2), assume the satisfaction of (IC1), and form the Lagrangian:

$$
\begin{aligned}
L= & \theta \pi_{1}\left[\delta_{1} R_{1}+\left(1-\delta_{1}\right) g-\rho\right]+(1-\theta) \pi_{2}\left[\delta_{2} R_{2}+\left(1-\delta_{2}\right) g-\rho\right]- \\
& \mu\left\{\pi_{1}\left[\delta_{2}\left(y-R_{1}\right)-b_{2}\right]-\pi_{2}\left[\delta_{2}\left(y-R_{2}\right)-b_{2}\right]\right\}+\lambda \pi_{1}\left[\delta_{1}\left(y-R_{1}\right)-b_{1}\right]+ \\
& \tau_{1} \pi_{1}+\tau_{2}\left(1-\pi_{1}\right)+\tau_{3} \pi_{2}+\tau_{4}\left(1-\pi_{2}\right) .
\end{aligned}
$$

Kuhn-Tucker conditions are FOC

$$
\begin{aligned}
\frac{\partial L}{\partial R_{1}} & =\theta \pi_{1} \delta_{1}+\mu \pi_{1} \delta_{2}-\lambda \pi_{1} \delta_{1}=0, \\
\frac{\partial L}{\partial R_{2}} & =(1-\theta) \pi_{2} \delta_{2}-\mu \pi_{2} \delta_{2}=0, \\
\frac{\partial L}{\partial \pi_{1}} & =\theta\left[\delta_{1} R_{1}+\left(1-\delta_{1}\right) g-\rho\right]-\mu\left[\delta_{2}\left(y-R_{1}\right)-b_{2}\right]+\lambda\left[\delta_{1}\left(y-R_{1}\right)-b_{1}\right]+\tau_{1}-\tau_{2}=0, \\
\frac{\partial L}{\partial \pi_{2}} & =(1-\theta)\left[\delta_{2} R_{2}+\left(1-\delta_{2}\right) g-\rho\right]+\mu\left[\delta_{2}\left(y-R_{2}\right)-b_{2}\right]+\tau_{3}-\tau_{4}=0,
\end{aligned}
$$

and (IC2), (IR1), $0 \leq \pi_{1} \leq 1,0 \leq \pi_{2} \leq 1$, complementary slackness conditions, and the non-negativity of multipliers.

Similarly, like in the case without intervention, multipliers $\lambda$ and $\mu$ are again found to be positive, the optimal values of $R_{i}^{*}$ are the same as in the case without intervention, and we obtain $\pi_{2}^{*}=1$. After substitutions for $R_{1}, \lambda, \mu$ into $\partial L / \partial \pi_{1}$, we obtain

$$
\begin{aligned}
\frac{\partial L}{\partial \pi_{1}} & =\theta\left(\delta_{1} y-b_{1}-\rho+\left(1-\delta_{1}\right) g\right)+(1-\theta) \delta_{2}\left(\frac{b_{2}}{\delta_{2}}-\frac{b_{1}}{\delta_{1}}\right)+\tau_{1}-\tau_{2}=0 \\
& \Rightarrow \pi_{1}^{*}= \begin{cases}1 & \text { if } \delta_{1} y-b_{1}-\rho \geq \frac{1-\theta}{\theta} \delta_{2}\left(\frac{b_{1}}{\delta_{1}}-\frac{b_{2}}{\delta_{2}}\right)-\left(1-\delta_{1}\right) g \\
0 & \text { otherwise. }\end{cases}
\end{aligned}
$$

The rest of the solution, checking our assumption about (IC1), is identical to the case without intervention. The proof for the part of solution corresponding to the case 
of lower symmetric information repayment of Type 2 borrower is done along the same lines as the part presented here.

Q.E.D.

\section{A.3 Proof of Proposition 3}

We will consider here only the case of lower symmetric information repayment of a Type 1 borrower since the case of alleviating redlining for the Type 2 borrower is proved in the same way. Using the same approach as in the situation without intervention, we form the Lagrangian:

$$
\begin{aligned}
L= & \theta \pi_{1}\left[\delta_{1}\left(R_{1}+s\right)-\rho\right]+(1-\theta) \pi_{2}\left[\delta_{2}\left(R_{2}+s\right)-\rho\right]- \\
& \mu\left\{\pi_{1}\left[\delta_{2}\left(y-R_{1}\right)-b_{2}\right]-\pi_{2}\left[\delta_{2}\left(y-R_{2}\right)-b_{2}\right]\right\}+\lambda \pi_{1}\left[\delta_{1}\left(y-R_{1}\right)-b_{1}\right]+ \\
& \tau_{1} \pi_{1}+\tau_{2}\left(1-\pi_{1}\right)+\tau_{3} \pi_{2}+\tau_{4}\left(1-\pi_{2}\right) .
\end{aligned}
$$

Since the structure of the optimization problem is identical to the case of credit guarantees intervention, the only difference in the Kuhn-Tucker conditions for these two problems is in

$$
\begin{aligned}
& \frac{\partial L}{\partial \pi_{1}}=\theta\left[\delta_{1}\left(R_{1}+s\right)-\rho\right]-\mu\left[\delta_{2}\left(y-R_{1}\right)-b_{2}\right]+\lambda\left[\delta_{1}\left(y-R_{1}\right)-b_{1}\right]+\tau_{1}-\tau_{2}=0, \\
& \frac{\partial L}{\partial \pi_{2}}=(1-\theta)\left[\delta_{2}\left(R_{2}+s\right)-\rho\right]+\mu\left[\delta_{2}\left(y-R_{2}\right)-b_{2}\right]+\tau_{3}-\tau_{4}=0 .
\end{aligned}
$$

Following the same strategy of proof as in the credit guarantees case, we therefore obtain

$$
\frac{\partial L}{\partial \pi_{1}}=0 \Rightarrow \pi_{1}^{*}= \begin{cases}1 & \text { if } \delta_{1} y-b_{1}-\rho \geq \frac{1-\theta}{\theta} \delta_{2}\left(\frac{b_{1}}{\delta_{1}}-\frac{b_{2}}{\delta_{2}}\right)-\delta_{1} s \\ 0 & \text { otherwise }\end{cases}
$$

Q.E.D. 
Arping, S., G. Loranth, And A. D. Morrison [2010], "Public initiatives to support entrepreneurs: Credit guarantees versus co-funding," Journal of Financial Stability, 6, 26-35.

Beck, T., L. F. Klapper, and J. C. Mendoza [2010], "The typology of partial credit guarantee funds around the world," Journal of Financial Stability, 6, 10-25.

Becker, G. S. [1964], Human Capital: A Theoretical and Empirical Analysis, with Special Reference to Education, National Bureau of Economic Research.

Besanko, D. And A. V. Thakor [1987], "Collateral and rationing: Sorting equilibria in monopolistic and competitive credit markets," International Economic Review, 28, $671-689$.

Bester, H. [1985], "Screening vs. rationing in credit markets with imperfect information," American Economic Review, 75, 850-855.

Bikker, J., L. SpierdiJk, And P. Finnie [2007], "The impact of market structure, contestability and institutional environment on banking competition," Working Paper 156/2007, De Nederlandsche Bank, Amsterdam.

BikkeR, J. A. AND K. HAAF [2002], "Competition, concentration and their relationship: An empirical analysis of the banking industry," Journal of Banking and Finance, $26,2191-2214$.

Chan, Y.-S. And G. Kanatas [1985], "Asymmetric valuation and the role of collateral in loan agreements," Journal of Money, Credit, and Banking, 17, 84-95.

Columba, F., L. Gambacorta, And P. E. Mistrulli [2010], "Mutual guarantee institutions and small business finance," Journal of Financial Stability, 6, 45-54. 
Cowling, M. [2010], "The role of loan guarantee schemes in alleviating credit rationing in the UK," Journal of Financial Stability, 6, 36-44.

DeMezA, D. And D. C. WebB [1987], "Too much investment: A problem of asymmetric information," Quarterly Journal of Economics, 102, 281-292.

DiAmond, D. B. [1997], "The promise and perils of interest rate subsidies: A survey of eight selected programs," Report for United States Agency for International Development.

European Commission [2009], "Temporary Community framework for State aid measures to support access to finance in the current financial and economic crisis," Official Journal of the European Union.

Fukanuma, H., T. Nemoto, And W. Watanabe [2006], "Do governmental financial institutions help startups grow? Evidence from Japan," Mimeo.

Gale, W. G. [1990], "Collateral, rationing, and government intervention in credit markets," in: R. G. Hubbard (ed.), "Asymmetric Information, Corporate Finance, and Investment," pp. 43-61, University of Chicago Press, Chicago.

Gelos, G. R. And J. Roldos [2004], "Consolidation and market structure in emerging market banking systems," Emerging Markets Review, 5, 39-59.

Hempell, H. S. [2002], "Testing for competition among German banks," Discussion Paper 04/02, Deutsche Bundesbank, Research Centre.

Honohan, P. [2010], "Partial credit guarantees: Principles and practice," Journal of Financial Stability, 6, 1-9.

INNES, R. [1991], "Investment and government intervention in credit markets when there is asymmetric information," Journal of Public Economics, 46, 347-381. 
JANDA, K. [2006], "Analysis of the budgetary costs of the Supporting and Guarantee Agricultural and Forestry Fund," Czech Journal of Economics and Finance, 56, 416434.

— [2008], The Theory and Practice of Government Credit Supports (in Czech: Teorie a praxe statnich uverovych podpor), Karolinum, Prague.

Mankiw, G. N. [1986], "The allocation of credit and financial collapse," Quarterly Journal of Economics, 101, 455-470.

Maudos, J. AND A. NAGore [2005], "Explaining market power differencies in banking: A cross-country study," Working Paper EC 2005-10, Instituto Valenciano de Investigaciones Economicas, Valencia, Spain.

Minelli, E. ANd S. Modica [2006], "Credit market failures and policy," Discussion Paper 0607, Universita di Brescia.

Neven, D. AND L.-H. RolLer [1999], "An aggregate structural model of competition in the European banking industry," International Journal of Industrial Organization, $17,1059-1074$

Pruteanu-Podpiera, A., F. Schobert, and L. Weill [2008], "Banking competition and cost efficiency: A micro-data analysis on the Czech banking industry," Comparative Economic Studies, 50, 253-273.

Smith, B. D. And M. J. Stutzer [1989], "Credit rationing and government loan programs: A welfare analysis," American Real Estate and Urban Economics Association Journal, 17, 177-193.

Stiglitz, J. E. AND A. Weiss [1981], "Credit rationing in markets with imperfect information," American Economic Review, 71, 393-410. 
TePly, P. [2007], "Regulation of bank capital and behavior of banks: Assessing the US and the EU-15 region banks in the 2000-2005 period," Working Paper 23/2007, IES FSV UK, Prague, Czech Republic.

UEsugi, I. [2008], "Efficiency of credit allocation and effectiveness of government credit guarantees: Evidence from Japanese small businesses," Working Paper 08-E-2, Bank of Japan.

Uesugi, I., K. Sakai, and G. M. Yamashiro [2006], "Effectiveness of credit guarantees in the Japanese loan market," Discussion Paper 06-E-004, RIETI.

WEILL, L. [2004], "On the relationship between competition and efficiency in the EU banking sectors," Kredit und Kapital, 37, 329-352. 


\section{Working Paper Series}

ISSN 1211-3298

Registration No. (Ministry of Culture): E 19443

(c) Karel Janda, 2011

All rights reserved. No part of this publication may be reproduced, stored in a retrieval system or transmitted in any form or by any means, electronic, mechanical or photocopying, recording, or otherwise without the prior permission of the publisher.

Published by

Charles University in Prague, Center for Economic Research and Graduate Education (CERGE) and

Economics Institute ASCR, v. v. i. (EI)

CERGE-El, Politických vězňů 7, 11121 Prague 1, tel.: +420 224005 153, Czech Republic.

Printed by CERGE-EI, Prague

Subscription: CERGE-EI homepage: http://www.cerge-ei.cz

Phone: + 420224005153

Email: office@cerge-ei.cz

Web: http://www.cerge-ei.cz

Editor: Michal Kejak

Editorial board: Jan Kmenta, Randall Filer, Petr Zemčík

The paper is available online at http://www.cerge-ei.cz/publications/working_papers/.

ISBN 978-80-7343-237-9 (Univerzita Karlova. Centrum pro ekonomický výzkum a doktorské studium)

ISBN 978-80-7344-228-6 (Národohospodářský ústav AV ČR, v. v. i.) 
CERGE-EI

P.O.BOX 882

Politických vězňů 7

11121 Praha 1

Czech Republic http://www.cerge-ei.cz 